\title{
Organic Food “Yes”, Organic Food “No” A Discussion between Specialists with the Italian Parliament in the \\ Fray
}

\author{
Aubert M1, Banas $\mathrm{D}^{2}$, Bernier $\mathrm{N}^{3}$, Blouin $\mathrm{M}^{4}$, \\ Bolzonella $\mathrm{C}^{5}$, Bonneval $\mathrm{K}^{6}$, Brun JJ ${ }^{7}$, Fritz \\ $I^{8}$, Giannini $\mathbf{R}^{9}$, Hager $\mathbf{H}^{8}$, Katzensteiner $\mathbf{K}^{8}$, \\ Lowenfels J ${ }^{10}$, Menta $\mathrm{C}^{11}$, Micheloni $\mathrm{C}^{12}$, Paoletti \\ MG $^{5}$, Pelosi ${ }^{13}$, Piccolo $A^{14}$, Ponge J F ${ }^{3}$, Singh $\mathrm{SK}^{15}$, \\ Tassinato $\mathrm{E}^{16}$, Teo $\mathrm{G}^{17}$, Tomasi $\mathrm{M}^{18}$ and Zanella $\mathrm{A}^{5 *}$ \\ ${ }^{1}$ UFR Sciences and Techniques, University of Rouen, \\ France \\ ${ }^{2}$ University of Lorraine, France \\ ${ }^{3}$ National Museum of Natural History of Paris, France \\ ${ }^{4}$ UMR Agroecology, Agrosup Dijon, France \\ ${ }^{5}$ University of Padua, Italy \\ ${ }^{6}$ Strasbourg School of Decorative Arts, France \\ TIRSTEA - Center of Grenoble, France \\ ${ }^{8}$ University of Natural Resources and Life Sciences, \\ Austria \\ ${ }^{9}$ University of Florence, Italy \\ ${ }^{10}$ Garden Writers of America, USA \\ ${ }^{11}$ University of Parma, Italy \\ ${ }^{12}$ Italian Association for Organic Agriculture (AIAB-FVG), \\ Italy \\ ${ }^{13}$ UMR 1114 EMMAH, INRA, Avignon University, France \\ ${ }^{14}$ University of Naples Federico II, Italy \\ ${ }^{15}$ Punjab Agricultural University, India \\ ${ }^{16}$ Wigwam Network, Italy \\ ${ }^{17}$ ColBel Farm, Pieve di Soligo, Italy \\ ${ }^{18}$ PAN Studio Associaton, Merano, Italy \\ *Correspondling author: Augusto zanella, Department \\ of Land, Environment, Agriculture and Forestry, \\ University of Padua, Italy
}

Received: December 16, 2019; Accepted: J anuary 10, 2020; Published: January 17, 2020

\section{Introduction}

Recently, a group of Italian people belonging to the SETA group (https://www.setanet.it/), encompassing some agronomists, some university academists, some farmers and some citizens interested in the debate addressed a letter to the Italian Parliament. The goal was to arrest a decree that the Government intends to apply for fostering organic farming.

With the present article, we would like to address to the Italian Parliament another point of view, to support the decree and promote a sustainable organic agriculture in all its different variants in Europe as elsewhere in the world.

\section{Letter Sent to the Parliament by the SETA Group}

"Dear Deputies and Senators of the Republic,

- $\quad$ From different sources, we learn that among the priorities

\section{Abstract}

The SETA group (Agricultural Science and Technology) sent a letter to the Italian Parliament advising them not to adopt a legislative measure that favors organic and biodynamic agriculture compared to the conventional one. Another group of scientists thinks instead that the Italian government should favor organic and biodynamic agriculture and explains its reasons. The current article lists the SETA letter and the point of view of other Italian and international ecologists, conomists, pedologists, ecologists, writers and artists, which are tendentially "protectors of nature" but not idealists. Nor are they so much in agreement with each other. Judge for yourself in scrolling through the Discussion chapter. The divergence leads to the "why" it is necessary to switch to organic farming not on the "need" to do so. There are also disappointments about the use of GMOs or the costs of highly technological agriculture.

The situation is such on planet Earth that it is necessary to involve the whole society to get out of it. In addition, politicians are also needed to structure the collective action that only if conceived by the whole society and not by individuals or by non-coordinated organizations can save our species. We are convinced that agriculture and soil are among the fundamental levers of this action.

Keywords: SETA; Humusica; Organic farming; Organic food; Food production; Global change; Agriculture; Biodynamic; Italian parliament
Austin Anthropol - Volume 4 Issue 1 - 2020

Submit your Manuscript | www.austinpublishinggroup.com

Zanella et al. (c) All rights are reserved of the new Government is the approval of the law decree 988 Measures for the protection, development and competitiveness of organic farming, agri-food and aquaculture production. Given that every farmer who is respectful of the law is free to produce as he wishes, we would like, as citizens and scholars, to call the attention of our institutional representatives the following concepts that most often do not find space in the public debate;

Organic crops are less environmentally sustainable than those with the conventional / integrated method. This is because they give rise to a 20 to $70 \%$ lower yield, in equal farmed areas, therefore their generalized extension would require 20 to $70 \%$ more land to become cropped, leading to a massive destruction of forests and natural grasslands;

Compared to conventional agriculture, organic farming leads to $50 \%$ higher greenhouse gas emissions in pea crops , $70 \%$ higher ones in wheat, and $300 \%$ higher ones in rice; emissions result moreover $61 \%$ higher per $\mathrm{kg}$ of bread produced; 
- Organic products are marketed at prices up to $150 \%$ higher than comparable conventional products (source: EU - https:// ec.europa.eu/info/news/organics-sector-rise-both- domesticproduction- and-imports-see-large-increases-2019-mar-07_en), which should lead us to reflect on the economic repercussions for the consumer (or for the State, when it comes to school canteens obliged to supply only organic products);

Organic products do not show significant differences with respect to the others in terms of healthiness or nutritional characteristics as emerges from the scientific work of [1] and from the EFSA reports on pesticide residues in food (https: //www.efsa. europa.eu/en/efsajournal/pub/5743);

Already today $45 \%$ of the net income of organic businesses is guaranteed by $\mathrm{EU}$ funding compared to $31 \%$ of conventional farming (source: Bioreport Crea, 2017-18 edition; Senate Research Department, note 108, June '19);

With the law decree 988 an esoteric practice like biodynamic agriculture, achieves a formal clearance, being equated to organic farming. The biodynamic method is certified by a registered trademark owned by a multinational company and features an average turnover per hectare of 13,309 euros against the 3,207 euros of conventional farms and the 2,441 of organic ones (source Bioreport Crea, edition 2017-18). We hope that this Parliament will not want to be remembered as a reverse Robin Hood who takes away from the poor to give to the rich;

Law Decree 988 refers to a niche sector (66773 organic and 286 biodynamic companies, which accounts for $4.5 \%$ of the $1,471,000$ Italian farms - source Bioreport Crea, ed. 2017-2018);

In conclusion we would like to point out that the law decree 988 promotes organic farming by appealing to an alleged "national interest" for such agriculture. As SETA group we wonder what national interest is meant to be guaranteed in a decree which not addressing the crucial issue of controls on organic productions, undermining the national seed system, weakening the university agricultural education system, introducing a plethora of unnecessary territorial bodies, and stimulating low-productivity farming, will further increase our dependence on foreign countries, which is already close to $50 \%$ of the national demand for wheat and animal feeds. In this context the support offered to an esoteric practice such as the biodynamic practice, in the same country that along with Galileo Galilei gave birth to the Scientific Method as a system of knowledge of natural phenomena, is particularly striking, sounding almost like a new abjuration.

For the SETA group - prof. Luigi Mariani”

The Point of View of Other Scientists (Authors of the Present Article) on the Future of Agriculture

We agree with the following points contained in the letter from the SETA group:

1) Organic products are sold at higher price compared to the others;

2) More accurate and safe controls over organic products should be done;

3) Agriculture is very important for humans.

For the rest, however, the different issues are unjustified. The authors claim that conventional agriculture is cheaper than organic farming but do not consider the costs related to

a) The environment (two aspects $->$ a1: pollution, climate alteration, soil impoverishment in structure, stability towards erosion and organic carbon reserves, biodiversity loss and $->$ a2. soil fertility and the ever-increasing effort with conventional machinery to keep yields at a high and not durable level),

b) Human health in an environment forced to cope with added chemicals and

c) The indebtedness for technological machinery, which is increasingly required from conventional farmers to keep up with market standards.

These oversights could have been tolerated 30 years ago, but not now. It is out of place today to continue to undermine the house in which we live. Organic farming and its different versions are answers that are certainly more sustainable than conventional ones. Sustainability is expressed in an already established organically operated agriculture in almost closed cycles for nutrients and organics, which leads to a natural soil fertility that is independent from a steady unidirectional flow of nutrients and much less dependent on fossil energy sources. Natural soil fertility is based on an increased content of organic matter (humus, to be precise) with associated higher soil biodiversity and microbial activity.

Today's agriculture (be it conventional, organic, integrated, precision-farmed, conservative, regenerative, biodynamic, agroecological) has the onerous task of feeding the planet, but at the same time needs to be environmentally and socially sustainable. Therefore, comparing systens just on the basis of economic costs is no longer acceptable as our chance of continuing to use the resources of this planet depends on its own stability. When the alternative is 'nofuture', any other issue comes to an end. The role of research is to provide scientific support to this critical path, without uncritically espousing partisan positions. Although Italy is the place where Galileus developed the scientific method, as stressed by opponents of the law project on organic agriculture, it is also the same country where he was imprisoned by his contemporaries.

Sustainability of the environment is a function of the extent to which we will rely on existing ecosystem services while balancing them with new technologies. If the perpetrators of the harmful consequences of intensive agriculture are to be sought, they are not among the farmers. Farmers in general follow the indications coming from science and the market. Probably as scientists and merchants we might have to pronounce a "mea culpa". When we believe in unlimited progress, we fail to consider natural resources as a precious good to be preserved for next generations. When we strive to grow plants in systems without soil and with artificial illumination, we are overlooking and turning our back to nature-inherited assets of earth and light as if we were already planning our escape to the next planet. This does not sound as a workable solution for an increasing population. 
On the opposite, we believe that cultivating and reconciling scientific and social spirits of humanity could lead to new levels of balance, in first instance a clearer view of the relationship between resources and the number of humans. And when we imagine how to go further, we should try to do it not just as humans but rather as Earth's ecosystems, where humans are not daring brains leading the forefront of reality but one of the biological species integrated in it.

In conclusion, there are at least three scientific reasons for preferring organic and biodynamic farming over conventional agriculture:

1) The best quality of the food produced (at least regarding pesticide content and flavour) and the positive consequences on human health;

2) The best conservation of planet's biodiversity;

3) The action of storing carbon in the soil in the form of humus with a consequent positive impact on climate change.

For the scientific basis of these three conclusions, instead of focusing on individual works, we prefer to refer the reader to three reviews $[2,3,4]$. They contain respectively 154,60 and 141 selected scientific publications with data or ecological proved deductions that support these conclusions. Other more specific references are given below in the discussion part and/or are reported at the end of the list of References.

Discussion among the Authors of this Article to Explore the Horizon of Agriculture on Planet Earth and Program the Future of Mankind

Surinder S Kukal, Ph D, FNAAS, FISSS - Professor and Dean, GS Khush Distinguished Professor - College Of Agriculture - Punjab Agricultural University, Ludhiana-141004, India

$\mathrm{I}$, as a Soil Scientist, believe in carbon cycle and whatever biomass has been created through photosynthesis and carbon dioxide should go back into the soil to sustain soil health as well as environment and reverse the disturbed carbon cycle.

But, in a country like India we need to feed millions and cannot expect to produce at the same rate as being done presently, at least during initial few years. However, I strongly believe in organic agriculture at first instance (as far as possible) and if required (of course it will be) followed by or in combination with Integrated Agriculture (IA). I see the integrated agriculture (with combination of organic inputs + need-based inorganic inputs) to sustain our environment and at the same time to sustain agricultural productivity.

Efrem Tassinato - Head Office Wigwam Clubs Italia. NonProfit Associative Network for the Fair, Solidarity and Sustainable Development of Local Communities

I agree and therefore certainly, I endorse the petition on behalf of the associative network I represent.

As soon as the definitive document is available, we will share it in the Wigwam Local Community network and, as far as we can, spread it even further.
Jeff Lowenfels - Scientist, Gardener and Writer, President of Garden Writers of America, Us. Books: Plant A Row For The Hungry/Teaming With Microbes, Teaming With Nutrients, Teaming With Fungi!

A resounding yes!

\section{Cristian Bolzonella - Phd Technicien at the University oof Padova, Economist}

Agriculture is changing. Moving from an intensive sector based on chemical fertilizers and chemical pesticides to an agriculture where the production process is integrated in the natural cycles.

This change is highlighted also by the recent proposals of the new Common Agricultural Policy (CAP). CAP is paid by European taxpayers who have declared their intention to continue to support agriculture in the future only if does not pollute and produce positive environmental effects.

The objective of the old post war agriculture namely the quantity products maximization in order to feed the growing population has reduced importance given way to other goals such as: production of high quality products containing the lowest chemical residues, land management with the maintenance of meadows and pastures through extensive farming and the direct support for small farm income which continues to be lower than other sectors.

Worldwide the undernourished population is significantly reduced. The hunger is not due to production but rather to distribution issues. New problem instead is the increasing number of obese people feed by junk foods.

In this new scenario, organic farming will be important even if the experience on the fields shows that it this no always-possible follow a strictly organic protocol. For instance, in the viticulture sector the number of treatments varies greatly depending on the climatic conditions. In the more humid region of France, North Italy, Austria, Germany the main disease is Plasmopara viticola. The fungi defense requires 15-20 treatments that using copper-based products will exceed the cap of organic regulation. On the other hand, in the drier areas such as South Italy, Spain, California, Argentina etc. 4-5 treatments are enough and organic rules are easily satisfied.

Do we eliminate viticulture from France, Germany, Austria and North Italy? It does not seem viable at all! Is it better to produce a "fake organic" or a "true sustainable" products according to the condition of the area? Personally, I think that it is preferable produce sustainable products with the minimum input of pesticides. Important give a clear and correct information on the production process.

The current technology permits to know in real time treatments done, products used and who sprayed the cultivation. This information should be public because the pesticides effects are public on water, air, etc. and on the health of the citizens. So if this data will be public there will be a new and healthy competition between farmers in order to reduce treatments and the use the less detrimental pesticides.

All we need is transparency and ethic!! This could be a new direct certification without intermediaries and without extra costs checked directly by the comments of the consumers and more in general by the citizens. A model already implemented in other sectors (TripAdvisor, booking etc.) but in this case who write a comment has to public "the 
real face" in order to avoid opportunistic behaviour. A model of social and environmental control that existed in the small village where all the people knows each other and where the reputation was important.

Sustainable agriculture should be based on the widespread use of bio indicators. We have to understand what nature is telling us. For example, a tool as hive with his bees' population give us many information about the health of the environment. A useful tool not only for farmers but also for all the inhabitants of a territory.

United Nations Organization has quantified pesticide victims in the agricultural sector for acute poisoning or poisoning at 200,000 a year, countless scientific studies have shown that exposure to pesticides prolonged over time - albeit in small doses - has important repercussions on health not only of those who work in agriculture, but of everyone [5]. A new agriculture is waiting at the door, an agriculture more complex that requires new environmental skills for the production of genuine products.

\section{Alessandro Piccolo - Full Professor of Agricultural Chemistry, Università Di Napoli Federico li. Chief Editor of "Chemical and Biological Technologies in Agriculture". Director of Cermanu Centro Interdipartimentale Di Ricerca Sulla Risonanza Magnetica Nucleare, Portici, Italy}

I fully agree with the letter. As you may know we were among the few who published scientific papers on biodynamic compost, and we intend to pursue in this scientific objective direction.

Spaccini R, Mazzei P, Squartini A, Giannattasio M, Piccolo A. Molecular properties of a fermented manure preparation used as field spray in biodynamic agriculture. Environmental Science and Pollution Research.

Giannattasio M, Vendramin E, Fornasier F, Alberghini S, Zanardo M, Stellin F, Concheri G, Stevanato P, Ertani A, Nardi S, Rizzi V, Piffanelli P, Spaccini R, Mazzei P, Piccolo A, Squartini A. Microbiological features and bioactivity of a fermented manure product (Preparation 500) used in biodynamic agriculture. Journal of Microbiology and Biotechnology.

\section{Jean-François Ponge - Professor by the Museum National D'histoire Naturelle, Cnrs Umr 7179, Brunoy, France}

I fully agree with the purposed letter. The point of view defended by the SETA group is a short-term vision of agriculture. It does not take into account the present and future health of mankind and, moreover, the need to live in a lovely planet. It is well-known that agricultural production does not increase anymore, even if the use of mineral fertilizers and pesticides is increasing and will still increase if nothing is done to arrest it. We cannot encourage conventional agriculture, rather we must discourage it, by helping farmers to turn to other, better sustainable, methods. Subsidies are necessary in a first time to achieve this target, acting as a primer to a self-reinforcing win-win process, like we know it in the soil when earthworms provide food to bacteria then bacteria to plants then plants to the soil through the decay of their dead parts.

Celine Pelosi - Chargee De Recherche Hdr, Centre De Recherche Provence-Alpes-Cote D'azur, Umr 1114 Emmah Inra-Avignon Universite

Studying the impacts of pesticides on some soil organisms for a few years, we brought some evidences that some currently used pesticides can harm non-target animals that provide key functions in soils, thus fragilizing the sustainability of agrosystems. I advocate a systemic approach to what is done and evaluated in the fields. Thus, not only do we have to consider farmers and consumers when thinking about the evolution of agriculture, but also we must account for the environmental legacy left behind (ecosystem quality for provision of services). The consequences of what we decide today can be long and difficult to observe but they affect the health of the ecosystems at long-terms and determine the orientations that we wish to give to our standard of living (health, recreational values of biodiversity, etc.). Although completely stopping pesticides is, for the moment, not so obvious to implement (integrated management being promising for instance), interfering in the adoption of environementally friendkly cropping systems is not so strategic to go towards more sustainable production systems

\section{Augusto Zanella - Professor of the University of Padova, Italy}

The Val Di Non, A Case Study: I was fond of scientific agriculture. During my university studies in 1982, with my father (I went with him to follow a particular course at the Institute of San Michele all' Adige, to learn how to do it) I destroyed a traditional orchard and replaced it with a modern one (it was said to be a "conversion"). The ancient grove was made of large apple trees up to $10 \mathrm{~m}$. To eradicate one of them, we utilized a big bulldozer (we couldn't remove it with a hoe, even after a day of work). When I went to pick apples on these old trees, I found bird nests (goldfinches, blackbirds) in the branches. The Renetta apples remained fresh all the winter in the home-cellar, maybe the peel became folded like old skin, but under it, their pulp was delicious and never powdery. The new trees we planted were produced in The Netherlands (at this time, Dutch researchers were the best of the world on this matter; and it is still the case, probably).

There were different trees' sizes: 1.5, 2, and 3, even one of 5 meters. Scientists advised the smallest because there was no need for stairs to pick the apples from them, one could stand simply beside trees. These trees were bearing fruit quickly, full production after 2-3 years, maximum 4 for the tallest. They had shallow roots and competed with herbs. It was not seen as a problem; at the end of their cycle (10 years of production), they were easier to replace. At the cooperative, they sold a weeding product that could be easily distributed, it was not dangerous for humans, no masks were needed. The grass dried out, leaving all the nutrients to the trees. Tree' roots did not take enough water, because they were confined at the surface and around the trunk. This, too, was not a problem; it was enough to implement a drip irrigation system. With my father, we ordered the new irrigation system sold with the apple trees, it didn't even cost so much. The ancient irrigation system was with high pinwheels that imitated the rain. The new water-supply plant was less expensive and much more effective. There was still a small problem that divided the producers: the plant protection products were no longer washed from the leaves by the irrigation system. This increased the efficiency of the products, but also the dust that was breathed when working in the countryside (some farmers showed allergies, not significant diseases, which were considered as physical weaknesses of the individuals, which were almost ashamed to have them). Apple growing has experienced many other technical innovations supported by the university and 
professional scientists of the Agricultural Institute of San Michele all' Adige (Trento, Italy).

In a few years, the landscape of the Valley changed. All the orchards were converted, and irrigation systems changed. Powerful cooperatives were born and finally turned on a single "Melinda". Farmers, even my father, had much more money. We changed the tractor, bought an "atomizer" for pesticide treatments, automated fruit harvesting machines, a flood of tools, built new roads. Today scientists drive from the Netherlands the computers that manage the apple production of the Valley. With a colleague who teaches students these things, I recently went to see a Val di Non's cooperative. Each apple is photographed 82 times, and then a computer classifies it and guides a mechanical hand that put the apple in the right container that ends up in controlled storage. The apples can be sold all over the world, taking advantage of the best market windows, even 10-12 months after the harvest.

The competition is fierce, the manager of the cooperative explained. Today with a phone call, you can have a load ready after 5-6 hours from the order, with apples of the desired size and quality, to be sent to all parts of the world. The primary market is China. They compete mostly with Romania and France apple producers, which knew the same development. When I asked him about the quality, he replied that they do tests before harvesting to determine the right time to collect apples. It is about the hardness of the pulp and about the "quality of the fabric that allows it to be kept longer, fresh and good in a controlled atmosphere". They spent millions to put apples in tunnels dug under the mountains in disused calcite quarries. I went to see them. It's something like science fiction, workers with helmets, lights, computers, wifi connected with satellites and trucks entering the mountain to pick up apples.

My father died in 1998, still believing in science. He was born in 1912 and had a hard time when young. He argued: "On TV they say we are experiencing a moment of “crisis". They don't know what a real "crisis" is. This is not a crisis, but "what do you want my mouth?" He thought that science solved the problems of hunger, even though towards the end of his life, he wondered where the "boat" was going. He often said: "There is no more religion". I know what he wanted to say, that there were no more principles of respect for the living and the environment; that it was enough to have so much and of everything. When he was down in the dumps, he also accused us of his children have ended up in a death trap. Two days before he died, he asked me: "Do you still believe in God?" I replied that I was a little lost. If God is the whole universe in evolution, with we all living inside Him, I believe that He still exists. My father proclaimed: "It is time for me to die, I no longer understand this world. Believe me, in the end, only God may help you, keep Him with you". When I came out of his bedroom, my mother (10 years younger) noticed my despair and said to me: "Don't pay excessive attention to father digressions, he still believes that there is a life after death, that sooner he will see his parents. The preservation of faith occupies a lot of time that perhaps could be invested differently by humans in search of peaceful satisfaction".

The small farms disappeared from Val di Non. One of my family too. It was a part-time occupation, and none of the members had time to do the job. The properties concentrated in the hands of a few producers who work night and day, often indebted and with powerful machinery. A young man I talked to is already trying to use drones. Precision agriculture tests are carried out using satellites, and the cooperative/region would partially finance future investments. The whole landscape is homogeneous and resembles a vineyard made of small trees. Hail protection turns the Valley into a greenhouse. I asked my brother up there whether sparrows are still there; he thinks he saw a couple near home. In Padua, I don't see these birds anymore (they were a lot of them in the 90s; sparrows, not pandas!). I remember there were so many when I was a child, that frrrrr flew away when you opened the door because they were chatting in the yard. There were also swallows that came back every year to nest under the balcony, beautiful, with a brown gag and a tail with two long spikes. My brother saw one more, in a village higher up and out of the way, just below the wood. I still buy Renetta apples at the Padua supermarket. They are still my favorite apples of all; I look for those from Val di Non and buy them. In addition, other varieties of Melinda apples, with names like Fuji, Gala, Granny Smith that were unknown in the Valley 20 years ago.

In the agricultural field, Veneto experienced the same evolutionary process as in Trentino, which can also be seen in other regions and throughout the whole world. Recently, I participated in the publication of an article about pesticides used in vineyards [6]. We found that the cost of the insecticide (the result also applies to fungicides) is inversely proportional to their potential damage to human health. There is the risk that to earn more, the farmers proceed with the purchase of products that are cheap and most dangerous for humans and the environment.

In Val di Non, organic apples are also produced (still not sold in Padva supermarkets). Organic apples sell better than others. 15\% of the total production of the Valley is organic, and every year this percentage increases by a few points. I think that this is a healthy and futuristic choice.

There is a problem nevertheless that concerns all the agricultural production of the planet: organic, for scientists, does not mean produced with the living organisms, but with as little as possible of them. The less their number, the better. It is enough to eliminate them with substances that, for now, we do not know whether they hurt or not. Once we discover that they hurt, we replace them with others that we hope won't destroy humans. These substances, also at the University of Padua, are still called and taught to students as Phytodrugs (plant-medicines).

A few days ago, on Sciences (https://www.sciencemag.org/ news/2019/11/new-genetically-modified-corn-produces-10-moresimilar-types), researchers presented transgenic corn that produces $10 \%$ more than other corn. How to say: in 4.5 billion years, Nature passed from a few cells to such millions of complex livings that we have not yet been able to fully inventory. Today, thanks to science, we humans succeed in fabricating new organisms that know how to take more resources than ever. They know how to avoid other bodies and grow faster than ever because we artificially put into them the potential of two or three organisms. This will lower biodiversity and give more resources to humans. Is this sustainable? Is this what we want? (Figure 1\&2). 


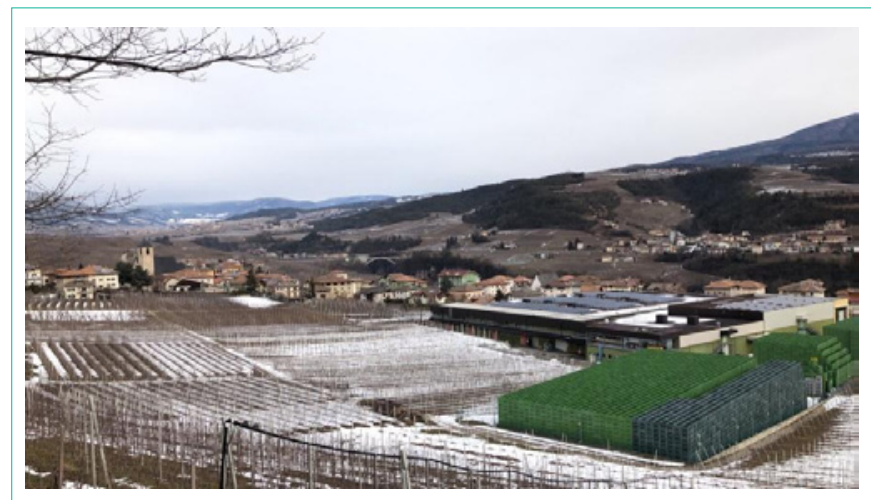

Figure 1: Tassullo, a village of 800 inhabitants in Val di Non. The hardworking people of the valley transformed the environment in which they live by keeping up with science. The beige parts are orchards in the winter season, planted higher and higher instead of the forest. In the foreground on the right is an apple cooperative deposit. In the village, the pace of work follows that of the phases of apple production.

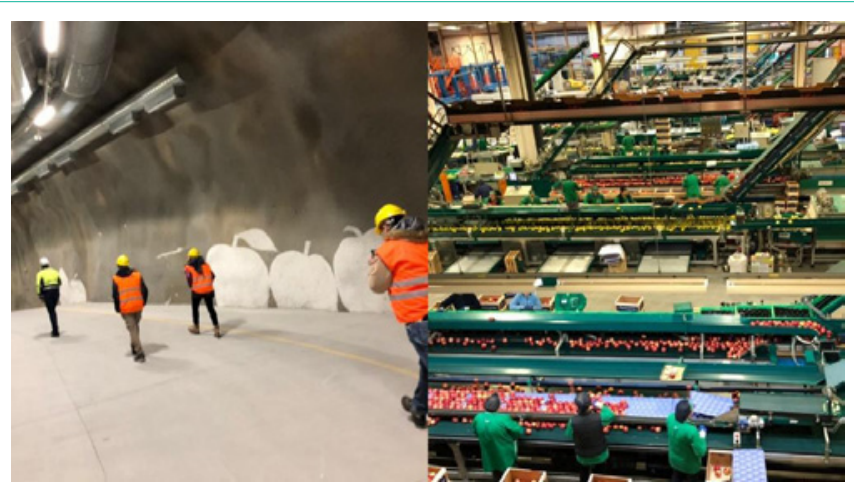

Figure 2: Val di Non. Left: after harvest, the apples are stored in the heart of the mountain, in cold rooms with a controlled atmosphere to preserve them for a long time and be sold at the right moment. The rock isolates the gas chambers and it has been calculated that the investment will be paid for with the energy savings achieved. The cooperatives provide jobs to local people on an ongoing basis. Instead, very tight work shifts are organized, and seasonal personnel is called to work from many parts of the world, at the time of the apple picking. The climate response of the valley has been studied and the harvest follows the ripening of the apples with cycles of a few days per band, predefined by specialized personnel. Right: automated preparation of apple loads to be exported throughout the world.

\section{Imaginary Dialogue between Galileo and Simplicio on Biodiversity and Agriculture}

Galileo looked around with his telescope. Then he said: The accounts don't add up.

Simplicio: You're wrong. We have more to eat than once; it is evident, blinds also see it. We would all starve without pesticides.

Galileo: Biodiversity is in freefall.

Simplicio: Fortunately. It is better because this leaves more food for us.

Galileo: The opposite is exact, the less the biodiversity and the less we will have to eat.

Simplicio: Never. We compete. If insects and pests eat everything, there is nothing left for us.
Galileo: There are no more harmful animals. Do you want to understand this, will you?

Simplicio: Mad. Soon we will have solar-powered drones that will take out the parasites one by one and without cost.

Galileo: Learn to live with parasites, feed them; they bring predators with them. They can't grow that much. If they grow, it means that the whole system is developing. We may destroy the natural balance that generated us. Let's try to remain in the entire living system.

Simplicio: For the love of heaven. He is becoming mad. Seal him up. If those of SETA feel the game, they will cut the balls to us too.

\section{Summarizing}

1) We need to change the type of agriculture.

2) Organic agriculture, biodynamic agriculture, and the halfway between these and the conventional are increasing. We think that to support organic farming with a decree is the right move, waiting for something different and more performing to arrive in the future.

3) The ideal would be agriculture that "works with all the living". As Masanobu Fukuoka created? (as he presented in "Natural farming") [7]. 4.5 billion Years ago, there was almost nothing alive on the planet Earth. Today, there are millions of different life forms. A wrong idea lives in modern scientific spirits that living beings are always in competition. I know that Malthus argued that human population growth will continue unchecked until regulated by external factors such as hunger and disease and that Wallace and Darwin fastened that idea into evolutionary theory. However, Darwin [8] found out above all that life forms a tree, with a trunk and many branches. Even infinite branches, because they will never stop "becoming." Sure, some went out, but many other branches will continue to grow and adapt to the future.

4) Dear Parliamentarians, you can decide in which agricultural future to go with your citizens. The SETA group fears hunger if the whole planet goes organic. However, we surely will starve if we continue as we did in recent decades. This prevision is scientifically recognized and corresponds to global warming, a decrease of biodiversity, pollution of the environment, lack of water in tropical and Mediterranean regions, human migrations ...

5) Copper is a big problem for the organic sector. Because it's a dangerous heavy metal. But it is perhaps the lesser evil. And there are already substitutes recommended by organic farming.

6) Biodynamic farmers don't hurt anyone, on the contrary. If all the world's farmers were biodynamic's, we would have less food (not sure) but no ecological problem (sure). And organic food quality is much better than conventional's [9-12].

7) The problems that humans have are above all economic. This means holding the money to eat and drink, having a home, starting a family, treating illness, supporting children when they are young and parents when they are old, all these simple and very material things. They are all tied to having a job. I would be more cautious about investments in GMOs and futuristic actions. Are we ready for them? Are we ready to go to Mars? Can we fix the house 
in which we live, first, and catalog / know the biodiversity that exists before creating new organisms? Can we focus a little more on people and families, and the places where they live on Earth, first, as enterprises, schools, and hospitals, to make life a little more serene for everyone? And if we stopped wars, how much money will we save to invest in a more sustainable economy?

8) Biodynamic agriculture and homeopathy touch a susceptible key that deserves a deepening up to the limit of our current knowledge: how much effect may single atoms or molecules, or even smaller particles have on the environment in which they dilute? The active principles of homeopathy (or biodynamic agriculture) make many scientists skeptical. However, there are no "minimal doses of matter". Particles that compose matter were "born" to react; they can't do anything else. We cannot grab tiny particles in the scale in which they work because, at that scale, they are objects that respond to still unknown laws. These laws can have strange effects on higher scales, not because particles or laws work poorly, but because the fact "appears" odd on an enormous scale and not corresponding to what is expected by humans. But it is ignorance, not witchcraft. We don't know why placebos work, do we? It is undoubtedly not the immaterial thought that physically heals the suffering. Yet it performs. Like a chain reaction that closely resembles the famous wing beat of a butterfly (http://eaps4.mit.edu/research/Lorenz/Butterfly_1972.pdf) that ends up causing a tornado. Recent re-examinations of Lorenz's paper suggest that it offered a significant challenge to the idea that our universe is deterministic, comparable to the challenges offered by quantum physics $[13,14]$.

9) Science should change its attitude towards facts that remain unexplained with current laws. We live in an infinite world. The theory of relativity and quantum physics have re-opened the mystery: the limits, if there are any, are so small or so large that the physical laws we know are no longer valid for understanding what is happening in limits' vicinity. These limits are part of our world; we should take them into account and "accept not to be able to understand everything". It is not true that experiments are "repeatable". Science cannot explain everything. Science makes mistakes. We know what life was like on the planet Earth millions of years ago, even when humans were not there. We have an idea about what light is, very approximate and theoretical, but it makes our phones work. Other facts remain hidden: how the matter was born, where the universe comes from, or what relationship exists between the birth of matter and light. Believing to comprehend how a plant and soil work is a huge mistake. We require more time. It could be fatal to humanity to think that the soil is not a living ecosystem.

10) Are there very safe vaccinations? Those should become mandatory. For other, less secure, the individual choice should prevail. The problem is not only scientific. As with everything: when money takes over, and we are always in the way, we need to double attention. For example, in an advanced society, non-scientific advertising should be banned. On television, today, all advertisements are more or less false. Then, it is not surprising that people no longer believe in doctors suggesting vaccinations.

11) The pigeons of our cities, for example, are good bioindicators. They get sick and lose their toes in noisy polluted and with a low percentage of green areas cities [15]. The more they are sick and lame, the more their host cities are dangerous to humans. There is no point in driving them out of the cities. It would be better to keep them close, green up the city environment, and check that the pigeons remain healthy and with good legs.

\section{Klaus Katzensteiner - Professor of the University of Natural Resources and Life Sciences, Vienna, Austria}

I am a forest ecologist and no specialist in agriculture and agricultural systems. Nevertheless, I share your concerns and fully support your intervention. I could tell similar experiences from my home in an intensively utilized agricultural landscape as you described from your parent's place: groundwater pollution, loss of biodiversity, soil erosion etc. Because of industrialized agriculture. In conventional agriculture, improved cultivation methods (partly copied from organic farming) have positive effects on water and soil quality over the last years. The continuing loss of structural diversity at the landscape level is, however, dramatic.

We all know the ipbes report on the status of our planet. It is our responsibility as scientists to act. I want to stay on the author's list, and I want to stay in dialogue, although I am no advocate of biodynamic or any other 'school' of farming.

As an ecologist, I believe in as far as possible closed nutrient cycles. As we well know from history, such closed nutrient cycles are not easy to maintain in agriculture, and an ever-increasing population needs to be fed. We know from history that science can contribute to the solution of problems but that the solutions can create new problems. Agricultural institutions have been established in the 19th century as a response to mis-harvests and famines, which were partly related to climatic extremes but also to 'soil nutrient mining'. HaberBosch supports food production but reactive nitrogen is threatening biodiversity and water resources, and radiative forcing of $\mathrm{N}_{2} \mathrm{O}$ contributes to the heating of the planet.

Can we escape such traps? An example of land use and landuse change from one of the regions where I study human-landscape interactions (Figure 3\&4): Mountain hill farming in the Himalayas functions as long as there are systems surrounding farm fields, which can be 'tapped' for nutrients. 1 ha of arable land needs $2-5$ ha of the forest as a nutrient source, be it exploited by grazing, lopping of trees or litter raking, the nutrients end up at the agricultural fields and

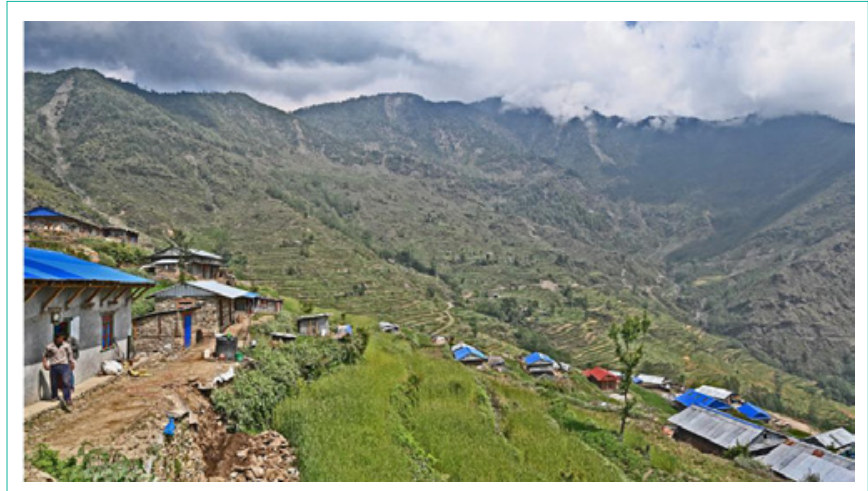

Figure 3: A hillfarming community in Nepal. Forests are degraded as a consequence of overutilization for agricultural purposes (cattle grazing, lopping of trees for fodder and fuelwood, litter raking (litter is used as animal bedding and the compost, mixed with urine and faeces is finally applied as a fertilizer to arable land). 


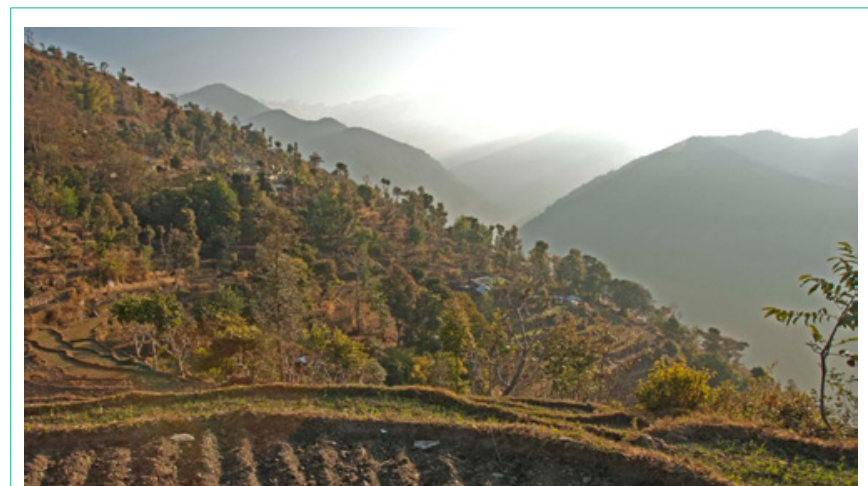

Figure 4: An agrosilvipastoral system in the Gaurishankar Conservation Area, Nepal. On farm trees provide fuelwood and fodder for cattle and mitigate the pressure on forest resources.

ensure 'sustained' food production. There are, however, 'carrying capacities' of the landscape. In our research area, the locally, mainly organically produced, food supply lasts for approximately 4-6 months, the rest is 'filled up' with rice and lentils imported from India, probably produced in an industrial way. Still, traditional landuse practices lead to severe degradation of forests.

We support community forestry, establishment of trees on farm boundaries and agroforestry in two remote communities within a carbon offset project. Participation is the key. Farmers and researchers from Nepal and from Europe learn from each other. In the end, decisions are taken by the communities! There is no single solution 'organic', 'dynamic', 'agroforestry', 'conventional', we try to practice 'adaptive management', carefully monitoring effects of our interventions.

'Our' villages are small living labs. Working there, I also see the capacity for transformation. And I can see how joint action can ensure survival. After the 2015 earthquake, almost every single house was destroyed completely. A whole settlement was threatened by landslides and had to be abandoned. When I was there a few months ago, most of the houses had been rebuilt (a whole new settlement on a safe place), the nursery which we jointly established produces seedlings: fodder trees and shrubs to be established on farmland, endangered but also economically valuable forest tree species to be planted on degraded forest land. The community members are behaving like the ones in the village of Astérix le Gaulois: quarreling and fighting, but if there is need, they are realy committed and ready for joint action. Are those actions the right ones? We do not know yet. However, if we don't try we will never know.

\section{Cristina Menta - Researcher and Director of Natural History Museum of Parma University, Italy}

Organic agriculture is a very counter-topic that also suffers from bad information. In my opinion, as soil scientists it is our job to help citizens and politicians to clarify some many doubts about topic.

I am convinced that organic agriculture is a good strategy to guarantee the future of our planet. In some of my previous studies [16-21] where we compared soil quality in terms of soil biodiversity and organic carbon content in different agriculture managements, we clarified the importance of an "conservative approach", that often shows higher soil biodiversity and complexity. I would like to consider this discussion not only from an environmental point of view but also from a farmer's point of view. During my experience, I met many organic agriculture farmers who strongly believe in a sustainable approach as an excellent strategy to link good food quality and respect for environment. I think that farmers attentive to the environmental problems, and not just to production, are the strength of agricultural system.

\section{Ines Fritz - Researcher by the Universität Für Bodenkultur Wien. Department Ifa-Tulln, Austria}

The demand for an ever-increasing amount of agricultural products at an ever-decreasing price is understandable from a narrow consumer's point of view. During the last several decades, this demand towed us, and not Italy alone, into a situation where we consider the product price as the one and only measure for wealth. We, as a society, forgot to see all the other cost, such as the loss of natural soil fertility, the contribution to climate change due to carbon release from soil, the loss of biodiversity and ecosystem resilience, the pollution of soil and groundwater, to name only a few of the most urgent.

Somebody will have to pay this bill. We may decide to not increase the debt for our children and grandchildren (such as the two references below) or we may decide to not care at all.

As a scientist, I took an oath to act in a responsible way for the benefit of all humans and for keeping our planet a worth living place: I do care!

Based on my scientific expertise, which lasts now for 25 years in soil microbial ecology, and inspired by many other scientists of the past and of the present who care about a sustainable form of living and care about our environment, I can't agree with any one-sided statement that has a chance to cause long-term damage for human mankind. To that end, I disagree with the SETA letter against law decree 988.

1. Francé-Harrar A, 1957. Humus - Bodenleben und Fruchtbarkeit (Engl: Humus - soil organisms and fertility). Bayerischer Landwirtschaftsverlag Bonn-München-Wien.

2. Fukuoka M, 2009. The one-straw revolution: An introduction to natural farming. $2^{\text {nd }}$ edition, New York Review Books Classics.

\section{Herbert Hager - Professor of the Universität Für Bodenkultur Wien, Austria}

I fully support the intervention in reponse to the SETA Group statement against Law decree 988.

I think organic agriculture needs all the ethical and argumentative support it can get and its environmental services are superior to modern "agribusinesses". Your personal experience with the changes in your home area Val di Non has moved my heartstrings.

But besides all the biodynamic and other close to nature land use systems I have missed in all the statements and interventions from different scientists something which can be organic farming but uses a mixed approach and which integrates (especially multipurpose) TREES into the land use system. I missed the mentioning of AGROFORESTRY. This land use system can improve 
the environmental services of the land use system, diversify products, improve family incomes and livelihoods and make the land use in the face of a changing climate also more resilient.

Agroforestry is now not only a land use system which is attractive to developing countries, Its innovative and nowadays an increasing number of famers in Europe are finding out its benefits and its easily combined with organic production, but it's still a box of many research questions to design optimal tree and crop interaction systems. See also the EURAF intiative. (http://www.eurafagroforestry.eu/welcome).

\section{Damien Banas - Professor of the Universite De Lorraine, France}

I am an ecologist in aquatic environments, and I teach agronomy students. Some young people, whose parents are farmers, are tired of hearing that farmers are polluters.

There is no doubt that pesticides kill (that's their function: to kill life), they pollute. To say the opposite would be to ignore it.

The aquatic environments I study are polluted by pesticides from the head of the catchment area. My research has shown that in agricultural watersheds, at few kilometres downstream from the source, the concentration of pesticides in the water is higher than the concentrations that could kill most phytoplankton (the basis of the nutrient resource of heterotrophic aquatic organisms) in 72 hours. However, it was not the farmers alone who wanted this use of pesticides. Since the Second World War, we (consumers, politicians, scientists) have asked them to produce more and faster. It is not that without pesticides it is not possible to produce a lot. However, it is easier to produce (without thinking) with pesticides. This change in agriculture, using fewer products that kill lives, must be accompanied and supported by politicians and consumers.

Wishing for more organic farming is not against progress. I am not in favour of denying progress. I think that scientists must help to fight against the current mistrust and esoteric discourses based on fears, beliefs, and not on scientific facts. Thus, the many discourses of mistrust of medical progress must worry us (e.g. discourse against vaccines, discourse against medical treatment in favour of so-called "alternative" medicine). Scientists must help to convey the messages confirmed by science (e.g. the benefit/risk ratio is very favourable to vaccines; medicine has increased life expectancy; homeopathy, whose effectiveness is equivalent to a placebo, cannot replace heavy medical treatments). As far as the use of pesticides is concerned, science has shown that they can be very toxic for life. So, if it is possible to avoid them, they must be avoided to preserve the environment and mankind. I do not think that we should confuse the refusal of progress with a desire for less pesticide use. These pesticides pollute soils, water and living things. This has, and will continue to have, an environmental and human cost in the future. I share your concerns and fully support your intervention. Producing with an understanding of prey/predator balance cycles is much more complex than simply applying pesticides. The progress is there. We must encourage better understanding in order to grow better with as few or no pesticides as possible.

To say that by promoting organic farming we will induce famine is false because we produce more than necessary. On the contrary, intensive agriculture, which encourages the production of a single

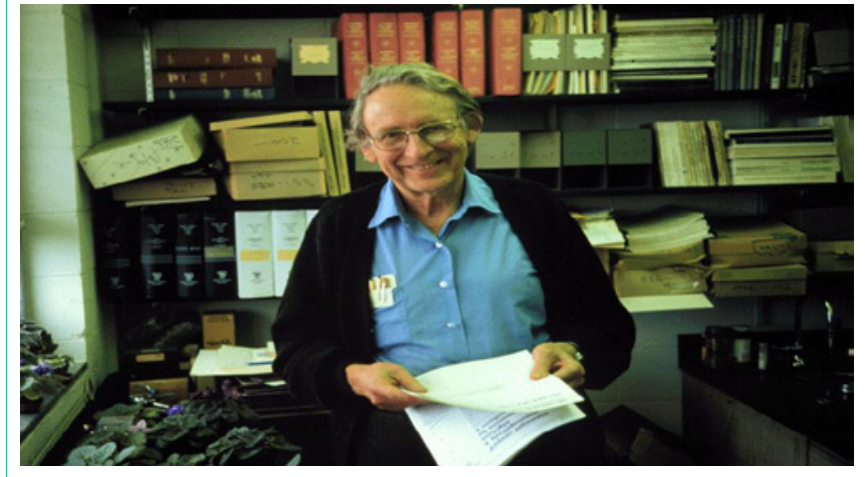

Figure 5: Prof. Eugene P Odum by the University of Georgia, Athens, Institute of Ecology. With his brother Howard T. Odum, they wrote Fundamentals of Ecology and are known for their pioneering works on ecosystem ecology and on industrial agrosystems [24,25] (Prof. Maurizio G Paoletti took photography in March 1981).

species over very large areas, exposes us to extreme vulnerability. Indeed, in the event of the appearance of a pesticide-resistant pest, it is this entire area, dedicated to a single crop that would be lost. To say that yields will fall by $70 \%$ is not true. Pesticide-free farming, with a farmer who takes into account prey/predator cycles, who understand his field and his crop, does not lead to such yield declines [22].

It's just a matter of will. It is possible to produce by reflecting on the functioning of nature, the ecosystem and the agrosystems. It is possible to produce with less pollution, without exposing the planet and animals (including humans) to pollutants that are often useless if we do not limit ourselves to basic agriculture.

Nicolas Bernier - Resercher by the Museum National D'histoire Naturelle - Departement «Adaptations Du Vivant» 4 Avenue Du Petit Chateau 91800, Brunoy, France

The concept of organic agriculture developed at about the same time as the expansion of chemical use, about 60-70 years ago. Paradoxically, the defenders of organic farming used arguments that were more ecological than related to public health. The humus was very often put forward as the seat of vital biological processes. As it was a sign of a global outcry, various "organic farming" movements rose almost simultaneously in the UK, New Zealand, Australia and the United States. They all described a dark future for our environment under the growing influence of so-called "phytosanitary" chemicals. Today, scientists of different disciplines as ecology, biology, pedology and climatology have not finished drawing the dark balance sheet of Seventy years of intensive agriculture: human poisoning (Cloredecone for example), disappearance of insects (Neonicotinoide for example), destruction of humus and soil organisms, disappearance of soil organic matter and global warming, catastrophic energy balance and agricultural production model based on industrial animal protein production, deforestation, destruction of agricultural jobs and therefore on the self-destruction ... In the end, the balance sheet is much more negative than predicted in the pre-war years. Yet, the lobbying of the so-called "conventional" agriculture is still extremely vigorous, always ready to untruths to play on the ancestral fears of the "bad harvest" and famines. Yet, everything suggests the opposite, the chemical destruction of life, the skeletonization of soil, the depletion of soil water resources are the real threats to human food. It is high 
time to rehabilitate the black gold that is humus and relearn to work with soil organisms.

Some well-known works supporting my statement:

1. Paull J. The Farm as Organism: The Foundational Idea of Organic Agriculture. Journal of Bio-Dynamics Tasmania.

2. Paull J. Australian Organic Farming and Gardening Society (1944), Australias Victorian Compost. Journal of Organics.

3. Paull J, nd Lord. Northbourne, the man who invented organic farming, a biography. Journal of Organic Systems.

4. Williams JC. The New Zealand Humic Compost Society: more than a garden club.

5. Bond V. HUMUS: the black gold of the earth. Tradition.

Cristina Micheloni, Agronomist, With 24 Years of Experience in Organic Farming; President of Aiab-Fvg (Associazione Italiana Agricoltura Biologica - Friuli Venezia Giulia)

In the SETA letter, the whole concept of efficiency and productivity is misused, while the scientifically proved positive effects of organic farming on soil, water quality and quantity preservation, biodiversity safeguard, human and animal health and welfare enhancement are neglected. If such aspects are taken into account, organic farming becomes clearly the most efficient food system.

On the other hand, there is stillroom for improvement within the organic system, in farming practices, in structuring of value chains and in the certification system. That is why organic needs more knowledge and research to keep on evolving. What we do not need at all is destructive unscientific criticism.

\section{Raffaello Giannini, Professor of Forest Genetics, Università Degli Studi Di Firenze, Italy}

I have never dealt with food in a strict scientific sense (except, if one can say, when I sit with my feet under the table twice a day, or when I enjoy cooking). I firmly believe in respecting the environment and above all in the value of biodiversity and genetic diversity. I devoted a lot of time and passion to genetics with great effort, in the hope that certain aspects and knowledge of the discipline in the field of forest ecosystems would be disclosed, disseminated and transferred to forest management. The term "biodiversity" is used by everyone, much even by forest scientists; the term "genetic diversity" is less used, yet everything is stored in it!.

Everyone today talks about food: Florence (not only) has become a manger. There are people who put the visit of the Uffizi Gallery on the same level as eating a sandwich in the shops of certain ancient streets. It is also true that that sandwich is necessary and cheap and those who supply it are very good at making it popular and in demand. Agricultural production: there is talk of revolutions and new technologies, which also means the widespread use of new and more effective energy inputs (how much do they cost and who produces them?). Do you eat too much meat? No problem: the synthetic one is produced, or the animal proteins are substituted with the vegetable ones, which must be supplied by the farmers themselves! Taking note that on the earth we are over 7 billion and everyone needs to eat (millions of hungry and tons of food are thrown away because they have expired), we are thinking of solving the problem with certain types of agriculture (also using strange terms such as "dynamic") . I suspect that the promoters are those who are interested in continuing to eat well and a lot, because they can offer all this to themselves!

Extremism does not lead to justice and freedom. It is right to recognize the tragic dimensions of the problems we are experiencing and that we know is growing. Precisely for this reason, I see the need to reflect, which does not represent a reason for denial but the search for the best compromise. Returning to the forest (because it is also subjected to stress), the coppice government is not an optimal use of the resource but is maintained by an economic sustainability which must be placed at the same level of environmental and social sustainability. The disaster is within the human being: in elementary schools we continue to teach history (to know it is fundamental) through the dates of battles and wars between humans, which are ancestral activities never abandoned. It is difficult to turn the other cheek. Discovering the chest for the opponent involves the danger of being hit in the heart more easily!

I am interested in learning about the development and the thinking that acts as a glue between the authors of this article, but also the deepening of the reasons that are supported in favor or against (GMO, organic cultivation, biotechnological culture, green or vertical forest) of various themes that underlie the aims of the work. Not least, the pleasure of increasing the interests that bind us all.

\section{Jean-Jacques Brun, Research Director, Institut National De Recherche EN Sciences ET Technologies, Environnement ET Agriculture (Irstea), UR Lessem (Laboratoire Ecosystemes ET Societes EN Montagne), Grenoble, France}

In mountain regions, it is interesting to note that the rural exodus (flight from farmers to cities) is beginning to turn into a metropolitan exodus (flight of exhausted city dwellers to the mountains). Young graduates are now leaving the big alpine towns to settle in the mountains. They often engage in a project of organic farming and/ or permaculture.

The young people who often felt instrumentalized in their work in the service of the dehumanizing "high-tech" find their personal coherence by recovering the broken links with the earth and the living. The Vercors plateau in the Grenoble region is a good example of this turnaround. Organic farming in the face of our fragmented and divided world is becoming a formidable school of reliance and resilience. This process is recent but many analysts predict that it will strengthen in the coming years. The revolution of rural territories is under way.

\section{Mauro Tomasi, Master in Forest and Environment Sciences, Forest and Environment Manager, Merano, Italy}

It is difficult to summarize in a few sentences what I sometimes feel towards the human species to which I belong. Those that count for our future are choices of society, and perhaps we are not evolved enough to understand that we have received life as a gift.

From professional experience, I can state that at the alpine level traditional, extensive agriculture played a positive role in terms of the biodiversity of the territory, operating the diversification of the landscape and creating new ecological niches for flora and fauna. 
In recent decades, with the aim of increasing yields, we knew a rapid and incessant process of mechanization and intensification of agricultural practices. To minimize competition with species that could influence production, humans decided to simplify and trivialize the natural areas cultivated, leading to a drastic reduction in the biodiversity associated with these environments.

In my opinion, organic farming represents a good compromise between these two extremes (the non-technological cultivation of the past and the chemical-physical exploitation of the present) and must therefore be absolutely supported.

\section{Manuel Blouin, Professeur En Ecologie, Agrosup Dijon, Departement Agronomie Agroequipements Elevage Environnement, Dijon, France}

The most important things to me is to recognize the selfdetermination of farmers. Farmers should develop a deep knowledge of the environment of their farms, which is specific. Agricultural practices should be adapted to each specific environment.

\section{Micael Aubert, Directeur Du Laboratoire Ecodiv Ea-1293, Université De Rouen, France}

It is tough for farmers to change the economic model of their farms. Behind organic versus conventional practices, there are two contrasted economic models, low versus high operating expenses. Above all, farmers are men and women like us, who need to eat, secure, and educate their children. Even if they managed to decrease their operating expense to reach a well-balanced budget, still depend on European subsidy after having sold their production. It is a discouraging situation. As soil ecologists, we should ask politicians to make decisions, but keep in mind that farmers have to extract themselves from an implemented economic system that imposed to increase production to feed population during the reconstruction after world war two.

\section{Maurizio G Paoletti, Professor of Ecology by the Univerity of Padova, Italy and of Agroecology by the University of Helsinki, Finland}

In the late 1980s, I was among the founders of IFOAM - Organics International at the University of California. In SantaCruz at that time there were Eugene Odum (Figure 5), Miguel Altieri, David Pimentel [23], Stive Gliesman, Ben and Deb Stinner and also Masanobu Fukuoca. Beyond the labels and protocols, sustainable agriculture is based on agroecology. Odum used to say that "we must produce with a strategy similar to the forest or the prairie", these are our models. So minimal external inputs, minimal or non-tillage, rotations, landscape design to promote biodiversity, importance of wild vegetation like hedgerows, woodlots living mulchs. Great was the interest in studying agricultural systems all over the tropics.

Whatever you call biodynamic or biological or sustainable agriculture it doesn't matter, it must look more like a forest or a prairie (Figure 6)! In Padua I organized three international conferences, I brought our technical colleagues to visit the four farmes model of sustainability in Ohaio. Unfortunately, little has changed in the cultivated fields. Nothing or almost nothing has happened in the Veneto University and in the agricultural worlds.

The food of a well-conducted organic farming is with all probability better and has the advantage of promoting greater

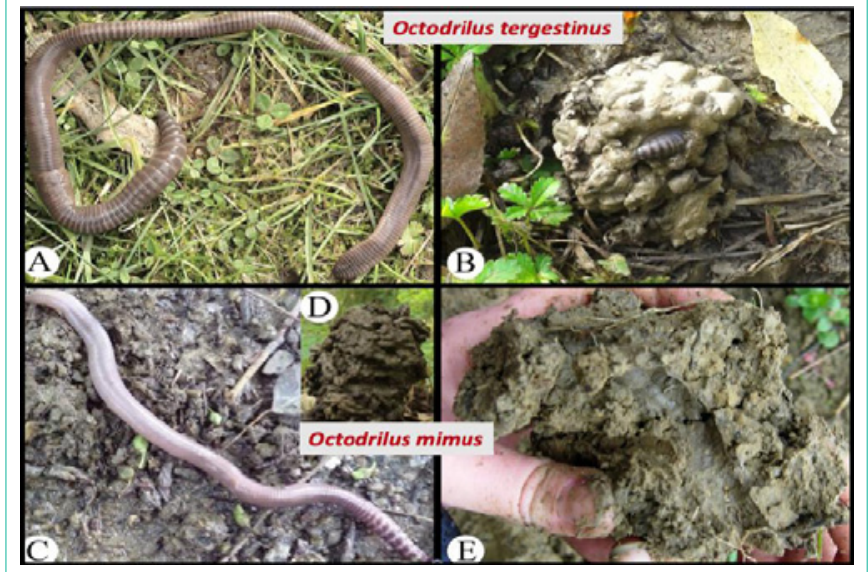

Figure 6: In a paper on agriculture we could not miss the engineering animals that create the chemical, physical and biological characteristics of the most productive soils in Europe. A and B Octodrilus tergestinus, adult specimen and new soil generated by the animal respectively; C, D and E Octodrilus mimus, adult, generated soil and a detail of its gallery. They are animals capable of incorporating organic substance and micro-organisms deep into agricultural soils over 1-2 meters.

biodiversity and reduce environment damages. I repeat if organic farming is well done!

Published works supporting my letter:

1. Paoletti MG, Stinner BR, Stinner D, Barbieri S, Crosato A, Pitton G, Silvestri G, Rebuschi C, Rongaudio R, Consalter A. Casi concreti di agricoltura sostenibile: riflessioni da un viaggio in USA. Veneto Agricoltura, 12, dicembre 1990.

2. Paoletti MG, Stinner BR, Lorenzoni GG. Agricultural Ecology and Environment. Proceedings of an International Symposium on Agricultural Ecology and Environment, Padova, Italy, 1988.

3. Paoletti MG, Pimentel D. Biotic Diversity in Agroecosystems. Paper from symposium on Agroecology and Conservation Issues in Tropical and Temperate Regions, University of Padova, Padova, Italy, 26-29 Septemer. 1990.

4. Gomiero T, Pimentel D, Paoletti MG. Environmental Impact of Different Agricultural Management Practices: Conventional vs. Organic Agriculture. Critical Reviews in Plant Sciences [23].

5. Fusaro S, Gavinelli F, Sommaggio D, Paoletti MG. Higher Efficiency in Organic than in Conventional Management of Biological Control in Horticultural Crops in North-Eastern Italy; Biological Control; Volume 97, June. 2016. [26].

6. Last Luisa, Michaela Arndorfer, Katalin Balazs, Peter Dennis, Tetyana Dyman, Wendy Fjellstad, Jürgen K. Friedel, Felix Herzog, Philipp Jeanneret, Gisela Lüscher, Gerardo Moreno, Norman Kwikiriza, Tiziano Gomiero, Maurizio G. Paoletti, Philippe Pointereau, Jaen-Pierre Sarthou, Siyka Stoyanova, Sebastian Wolfrum, Roland Kölliker 2014. Indicators for the on-farm assessment of crop cultivar and livestock breed diversity: A survey-based participative approach. Biodiversity and Conservation. 


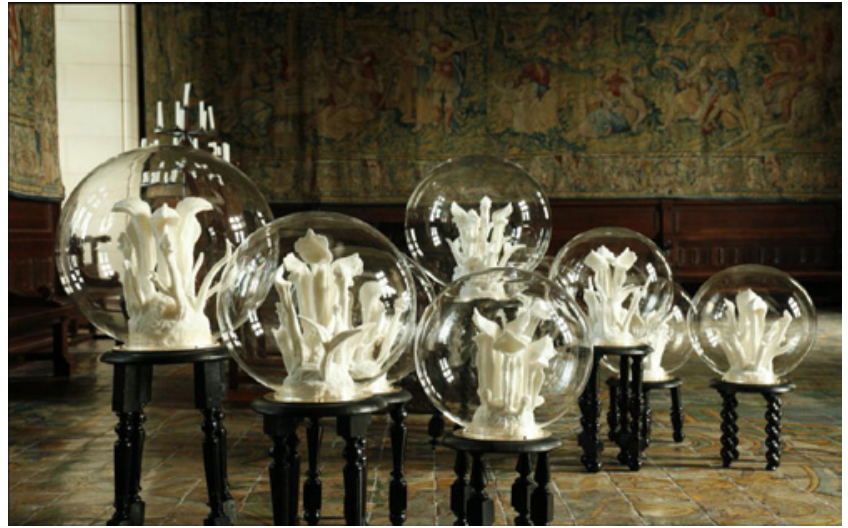

Figure 7: Confined ecosystems.

\section{Gianni Teo, Agronomist, Owner of Colbel Farm, Conegliano-Valdobiadene Prosecco Docg, Italy}

I have a degree in agronomy, and I own a farm. I wanted to communicate something that seems appropriate to conclude this nice article: we no longer convert to organic farming out of passion but out of necessity.

I started 15 years ago. I live in the middle of my vineyard. The vines around the house have been organic for quite a few years; all the others will be in the coming years. Once upon a time one could live in the vineyards. Today we switch to organic or biodynamic, or, to be safe, we need to go to live with the family elsewhere during growing season. Of course, the work is not lacking and mostly done without using tractors. I even adopted few beehives just outside the vineyard. I do not collect the honey, but I need them as bioindicators. It works; bees are fine. The microclimate is good and make it possible to live well with the vineyard at the kitchen window. Other farmers do the same. If others can go a little further with the old methods, it is because they can rely on us to take care of the environment.

\section{Artistic Perspectives}

\subsection{Karine Bonneval - Ecole Des Beaux Arts D’angouleme,} France

I propose two complementary reflections (Figure 7\&8).

The first shows a controlled nature, made of bleached and ascetic ecosystems, protected in crystal spheres.

Original title: Saccharomania, domaine de Chaumont sur Loire, 2017. Plantes carnivores en sucre encloses en Victorian Wardian cases (critique de l'histoire de la culture du sucre).

The second illustrates a human attempt to become "vegetable", at least partially. Such an attitude makes humans lose face.

\section{PS: Is There a Way to Cope with Global Warming?}

There is a rather simple one: to organize a first world cellphone referendum with this question: Would you protect and enter the average air temperature of planet Earth (mean surface aitr temperature $=15 \pm 3^{\circ} \mathrm{C}$ ) in the UNESCO WORLD HERITAGE LIST?

During the Tokyo Olympic Games in July 2020. Just sign here:

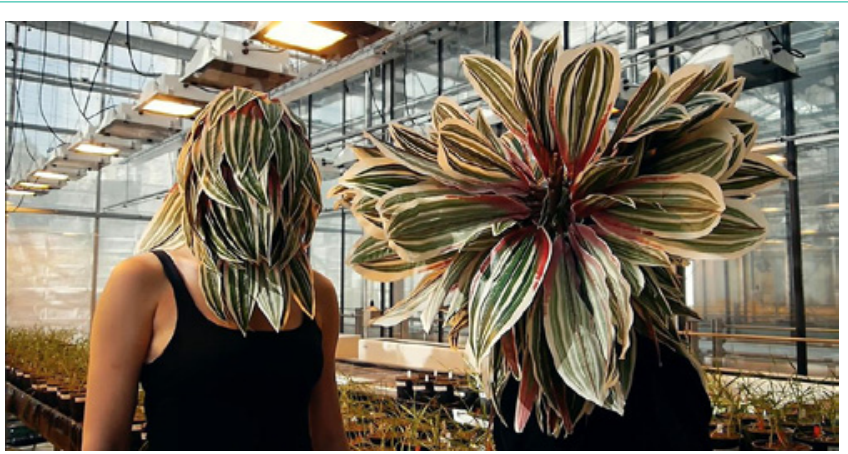

Figure 8: Communication. Original title: Extrait du film Devenir-plante (manger la terre), 2017.

https://secure.avaaz.org/it/community_petitions/Toshiro_ Muto_Tokyo_Organising_Committee_of_the_Olympic_ Games_2020_As_planet_Earth_citizens_will_you_stop_the_ climate_fro/

\section{References}

1. Dangour A, Dodhia S, Hayter A, Aikenhead MA, Allen E, Lock K, et al. Comparison of Composition (nutrients and Other Substances) of Organically and Conventionally Produced Foodstuffs: a Systematic Review of the Available Literature. Report for Food Standard Agency. London School of Hygiene \& Tropical Medicine. London. 2009.

2. Zanella A, Bolzonella C, Lowenfels J, Ponge JF, Bouché M, Saha D, et al. Techno Humus Systems And Global Change - Conservation Agriculture And 4/1000 Proposal. Applied Soil Ecology. 2018a; 122: 271-296.

3. Zanella A, Geisen S, Ponge JF, Jagers G, Benbrook C, Dilli T, et al. Techno Humus Systems And Global Change - Three Crucial Questions. Applied Soil Ecology. 2018b: 122; 237-253.

4. Zanella A, Ponge JF, Hager H, Pignatti S, Galbraith J, Chertov O, et al. Techno humus systems and global change - Greenhouse effect, soil and agriculture. Applied Soil Ecology. 2018c: 122; 254-270.

5. Abitabile C, Marras F, Viganò L. Bioreport 2017-2018. L' agricoltura biologica in Italia, ReteRurale. EU - MIPAAFT - CREA. Roma. 2019.

6. Bolzonella C, Lucchetta M, Teo G, Boatto V, Zanella A. Is there a way to rate insecticides that is less detrimental to human and environmental health? Global Ecology and Conservation. 2019; 20: e00699.

7. Fukuoka M. The Natural Way of Farming-The Theory and Practice of Green Philosophy. Japan Publications translator: Frederic P. Metreaud. 1985.

8. Darwin C. The Formation of Vegetable Mould Through the Action of Worms, with Observations on Their Habits. John Murray, editors. In: London. 1881.

9. Barański M, Średnicka-Tober D, Volakakis N, Seal C, Sanderson R, Stewart $\mathrm{GB}$, et al. Higher antioxidant and lower cadmium concentrations and lower incidence of pesticide residues in organically grown crops: a systematic literature review and meta-analyses. The British Journal of Nutrition. 2014: $112 ; 794-811$.

10. Baxter GJ, Graham AB, Lawrence JR, Wiles D, Paterson JR. Salicylic acid in soups prepared from organically and non-organically grown vegetables. Eur. J. Nutr. 2001; 40: 289-292.

11. Benbrook CM. Minimizing Pesticide Dietary Exposure through the Consumption of Organic Food. The Organic Center for Education and Promotion. 2004.

12. Benbrook CM. The impacts of yield on nutritional quality: lessons from organic farming. HortScience. 2008.

13. Palmer T. "The Butterfly Effect - What Does It Really Signify?". Oxford U. Dept. of Mathematics Youtube Channel. 2017.

14. Kerry E. "Edward N. Lorenz and the End of the Cartesian Universe". MIT 
Department of Earth, Atmospheric, and Planetary Sciences Youtube channel. 2018.

15. Jiguet $F$, Sunnen L, Prévot AC, Princé K. Urban pigeons losing toes due to human activities. Biological Conservation. 2019; 240: 108241.

16. Ghaley BB, Rusu T, Sandén T, Spiegel H, Menta C, Visioli G, et al Assessment of benefits of conservation agriculture on soil functions in arable production systems in Europe. Sustainability. 2018; 10: 794

17. Menta C, Leoni A, Tarasconi K, Affanni P. Does compost use affect microarthropod soil communities? Fresenius Environmental Bulletin. 2010; 19: $2303-2311$

18. Menta C, Leoni A, Gardi C, Conti F. Are grasslands important habitats for soil microarthropod conservation? Biodiversity and Conservation. 2011; 20: 1073-1087.

19. Menta C, Tagliapietra A, Caoduro G, Zanetti A, Pinto S. Ibs-Bf and Qbs-Ar Comparison: Two Quantitative Indices Based on Soil Fauna Community. EC Agricul-ture. 2015; 2.5: 427-439.

20. Menta C, Bonati B, Staffilani F, Conti FD. Agriculture Management and Soi Fauna Monitoring: The Case of Emilia-Romagna Region (Italy). Agri Res \& Tech: Open Access J. 2017; 4: 555649.
21. Tabaglio V, Gavazzi C, Menta C. Physico-chemical indicators and microarthropod communities as influenced by no-till, conventional tillage and nitrogen fertilisation after four years of continuous maize. Soil \& Tillage Research. 2009; 105: 135-142.

22. Adeux G, Vieren $E$, Carlesi $S$, Bàrberi $P$, Munier-Jolain $N$, Cordeau $S$. Mitigating crop yield losses through weed diversity. Nature Sustainability. 2019; 2: 1018-1026.

23. Gomiero T, Pimentel D, Paoletti MG. Environmental impact of different agricultural management practices: conventional vs: organic agriculture. Crit. Rev. Plant Sci. 2011; 30: 95-124.

24. Coleman DC, Odum EP, Crossley DA. Soil biology, soil ecology, and global change. Biology and Fertility of Soils. 1992; 14: 104-111.

25. Odum EP, Barrett GW. Redesigning Industrial Agroecosystems. Journal of Crop Improvement. 2004; 11: 45-60.

26. Fusaro S, Gavinelli F, Sommaggio D, Paoletti MG. Higher efficiency in organic than in conventional management of biological control in horticultural crops in north-eastern Italy. Biol. Control. 2016; 97: 89-101. 